\title{
Effectiveness of Accounting E-Book Oriented to Problem-Based Learning Model
}

\author{
Dwi Puji Astuti ${ }^{1 *}$, Kardiyem ${ }^{2,}$ Saringatun Mudrikah ${ }^{3,}$ Slamet Fauzan $^{4}$ \\ 1,2,3 State University of Semarang \\ ${ }^{4}$ State University of Malang \\ *Corresponding author.Email: dpastuti@mail.unnes.ac.id
}

\begin{abstract}
Educational progress and development cannot be separated from learning media innovation. Innovation is strongly required to improve learning quality. One example of the learning media innovation is electronic books that are currently widely-spread and gradually replace the existence of manual textbooks or commonly known as e-books. The purpose of this research is to identify the effectiveness of the use of ebooks on the Problem Based Learning (PBL) method in improving the students' learning outcomes. The research is conducted in SMA Negeri 4 Surakarta, and it is a research \& development research that adapts the developmental research steps proposed by Borg \& Gall. The data are collected using observation, interview, questionnaire, document analysis, and tests. The data are analyzed using descriptive and inferential statistical analysis methods. The descriptive statistical analysis includes the analysis of experts' validation and questionnaire data. The action is done by comparing the results of the pre-test and post-test. The results show that accounting e-book oriented to PBL can effectively improve student learning outcomes.
\end{abstract}

Keywords: E-book, Problem Based Learning, Learning Outcomes

\section{INTRODUCTION}

Tight globalization competition strongly demands the development of quality human resources. Education is one of the vital factors in human resources development. One of the most prioritized issues to be immediately solved is the quality of education itself. The government has implemented various ways to improve the quality of learning. Based on the Vision of National Education, the Ministry of National Education is currently struggling to achieve competitive and intelligent Indonesian people targeted in 2025, thus education is very important for the life and survival of the nation [1].

The phrase "competitive and intelligent Indonesian people" means that the Indonesian people must be spiritually, emotionally, socially, intellectually, and kinesthetically intelligent. Therefore, the improvement of the quality of education is an absolute need for human resources development and character building for national progress and development. One of the strategies used to achieve the goal is through the implementation of an appropriate educational curriculum.

Indonesia is currently implementing the 2013 curriculum. It aims to improve the quality of learning. The curriculum emphasizes the learningby-doing method to train the students' skills through scientific learning or scientific approaches [2]. The 2013 curriculum focuses on the students as the learning centers. They are required to be active and always take part in the learning activities. Educators can function as facilitators and help solve problems faced by students during learning. The success key of the 2013 curriculum is very much influenced by many factors, including the leadership of the school principals, teachers' creativity, students' activities, socialization, facilities and learning resources, a conducive academic atmosphere, and participation of other school members.

The results of observations on the learning process and interviews with some students of SMA Negeri 4 Surakarta generate the following 
information: a) the accounting learning process is less attractive, and the teacher only applies the lecturing method and is teacher-centered; b) most of the teachers do not yet utilize the learning media optimally so that the students are less enthusiastic in learning activities; c) the textbooks still become the main learning sources, so that the learning process does not attract the students' interest. His kind of conventional method makes the students are less interested in learning to account and they cannot maximize their potential so that it affects their learning outcomes significantly. It can be seen in their test scores, where only $47.5 \%$ of students get scores higher than the Minimum Criteria (KKM). This indicates that students' learning outcomes must be improved as soon as possible.

The low learning outcomes have been the most crucial problem that must be solved immediately particularly in the accounting subject. It is also caused by the use of learning media inappropriately. The teachers use less varied media. Meanwhile, they play an important role to create innovative education through the use of innovative media which ultimately improves the learning quality. The Internet can be used to find existing interesting media easily or modified in such ways to be a learning tool that supports the learning process. A real influence of technology on the educational fields is the progressive development of electronic books to replace the printed ones. The paper books are re-produced and converted into electronic forms known as e-book.

An E-book is an independent presentation of learning materials arranged systematically in an electronic format [3], [4] The students can explore their knowledge by learning the materials presented in an e-book. The E-book has more advantages than other types of educational media, such as it is easier to use for learning in various places, can be used at any time, and increase the students' motivation support their activities in academic achievement [5], [6]. These advantages will be able to motivate the students' learning independence and trigger their enthusiasm for learning so that they can improve their learning outcomes. Some experts have agreed that e-books are the media needed for the development of future education [7], [8]

The E-book must be supported by appropriate and effective learning models. An active and interesting learning atmosphere will be presented using a PBL Model. This model will analyze problems in the real world to train students to think critically in solving existing problems [9], [10].
According to [11], one of the advantages of the PBL model is that the students have a good opportunity to be actively involved in the problemsolving process so that they can be motivated more in the learning process. [12] explained that the effectiveness of the PBL learning model causes the students to be more active in thinking and understanding the materials both within groups or individuals by investigating the real problems around them so that they can get a deeper and more meaningful impression about what they have just learned.

So, it is hoped that the e-book equipped with the PBL model can make students more active, have a pleasant learning experience, and be able to complete assignments independently, so that the learning process will be interesting and teachers can easily manage the class. The purpose of this study was to determine the effectiveness of accounting e-books supported by problem-based learning models to determine student learning outcomes.

\section{LITERATURE REVIEW}

\subsection{E-Book}

The development of technology and information gradually shift the printed media to the digital one. Information and publications that were initially only documented and disseminated through printed papers are now written in electronic forms. This electronic form is called an e-book or digital book.

The appearance of the E-book is attractive with a practical and dynamic multimedia form [13]. Meanwhile, [14] stated that e-books are books that can be displayed electronically using a computer. [15] stated that electronic books are multimedia devices that can display text information to users. E-books are usually an electronic version of the printed output, but there are also e-books without a print version.

Electronic books or e-books offer the students and teachers interesting additional media that can support or enhance the learning process. E-books can integrate sounds, graphics, pictures, animation, and movies in one frame so that the presented information presented is richer than using conventional ones.

\subsection{Advantages of E-Book}

Each learning medium has its advantages and disadvantages. The E-book has some typical advantages compared to other types of media, 
although no one guarantees that e-book will completely replace all printed books any time soon. However, shifting printed books to electronic ones is inevitable, and will happen very soon. Some advantages of an e-book according to [16] are:

1.2.1. Flexibility; e-book makes it easy for anyone to have a mobile library that can be brought and accessed anywhere.

1.2.2. Functions; the functions of the e-book depend on the programs of its creators and types of electronic documents. Using these programs, we can search and find specific information, change the letter size, underline text, increase the font size, mark (bookmark), open the links, and print them into concrete forms.

1.2.3. Convenience; e-book makes it easy for users to scavenge any information on-line.

1.2.4. Price; mass marketing of e-books is cheaper than the printed version.

1.2.5. Space; e-books have the capacity of space on the computer hard disk because the entire encyclopedia can be stored within. Also, it can save file storage space, money, and time to delete, sort, edit, and replace files or content from e-books.

1.2.6. Availability; compared to printed ones, ebooks are more efficient because they are made in electronic or digital forms.

1.2.7. Publishing e-book is very efficient and economical and can increase the quantity and variety of information.

1.2.8. Conservation; using e-books, we can help to preserve nature and reduce pollution caused by the paper manufacturing process.

The E-book has many advantages over other types of educational media. It is easier to use anywhere and anytime [5]. Besides, the e-book can be well designed to increase the students' activeness, and they can also learn independently to help develop the learning process properly. [6] stated that the main advantage provided by e-books is increasing the students' motivation to learn and develop their academic achievement. By using ebooks, they can easily access, organize, and find titles and texts. Also, e-books can be loaded on tablets and cellphones which makes it easier to read them anywhere and anytime.

\subsection{Problem Based Learning (PBL)}

Problem-based learning is defined as learning that is carried out by trying to solve or manage real-life problems [17]. [18] stated that "PBL has a very structured flow and has a learning flow that brings the real world to the material".

The implementation of PBL emphasizes collaboration in building knowledge and teambased learning activities that take advantage of new collaborative tools (such as blogs, virtual worlds, simulations, games (gaming), discussion forums, chats, etc.) which can facilitate the students to interact and improve their learning achievements and outcomes [19], [20].

The students' learning achievement has significantly improved compared to the learning process using conventional methods because PBL is a learning model that involves them directly in a subject and provides practices [21]. This is in line with the conclusions of [22] that the PBL model can encourage the students to think critically through planning, arguing, asking questions, solving problems, analyzing, and providing solutions to the problems at hand. The PBL model enforces them to learn to solve problems both individually and in groups in the learning process so that the learning process becomes more exciting and meaningful.

The PBL model is designed for the skills development for participation in social democratic processes through a combined emphasis on interpersonal and academic inquiry skills [23]. One of the advantages of the PBL method is that the students have a better opportunity to be actively involved in the problem-solving process so that they are motivated more in the learning process [11]. [12] explained that the strength of the PBL learning model is that the students can be more active in thinking and understanding the materials in groups by investigating the real problems around them so that they get a deeper and more meaningful impression about what they are learning.

\subsection{Learning Outcomes}

Learning outcomes are an integral part of the learning process. Learning outcomes means the students' abilities they own after having knowledge transfer in the learning process. [24] stated that "Learning outcomes are written results that explain the achievements that have been made by students during the learning process". Learning outcome is people know and understand, and the abilities to do something at the end of the learning process and are also defined as knowledge, abilities, and competencies [25]. 
Learning outcomes are cognitive, affective, and psychomotor competencies or abilities that students have after experiencing a learning process [26], [27]. Learning outcomes include the cognitive, affective, and psychomotor domains [28]-[30]. When the learning is conducted at schools or especially in classrooms, teachers are the most responsible ones for generating good students' learning outcomes results. The students' mastery of the learning materials becomes a benchmark for the extent to which they understand the knowledge delivered by the teachers in learning activities. The learning process must influence students' learning outcomes. Therefore, the learning components must be prepared and used optimally to improve learning quality.

\subsection{E-Book based on Problem Based}

\section{Learning to Improve the Students' Learning}

\section{Outcomes}

E-books are prepared by presenting independent teaching materials that are systematically arranged in an electronic format [31]. E-books are developed using interactive digital technology supported by attractive layouts and contents to facilitate the users in using and reading them.s

The learning process using the PBL learning model involves the students' activeness to solve problems given through assignments and exercises. The PBL learning model tries to change conventional learning patterns into more active ones to support and encourage the students to be more actively engaged in learning. The PBL learning model trains the students to solve real problems to build their knowledge, and also improve their problem solving skills and critical thinking skills.

This is following the opinion of [22] who stated that the PBL learning model is a learning strategy that can stimulate the students to find problems and analyze, integrate, and solve them in groups. The main target of the PBL learning model is the students so that the teachers only play a role as a facilitator or as a guide for the learning activities. Learning activities will be more exciting and live because it is dominated by the students' activeness. Also, they will be more courageous in expressing their opinions without fear of being wrong.

The e-book media based on PBL is used as an independent learning resource to improve the students' understanding and competencies that must be mastered in the learning process. The development of e-book media based on PBL can improve the students learning outcomes [32]-[34].

The media development is intended to improve the students' understanding of the concept of accounting subject more deeply and improve their critical thinking skills and the ability to solve accounting problems which can then improve their learning outcomes. [35] in their study in South Korea found that digital books had a positive influence when combined with the PBL model.

The e-book based on PBL model can support the learning activities, one of which is in the form of a soft file in .exe format (executable file) which can be operated via a computer, laptop, or smartphone. The e-book based on PBL makes it easier for the students to learn independently because the e-book is presented clearly, and contain many questions designed as exercises and prepared as interesting as possible to raise the students' motivation to learn so that their learning outcomes can be optimal later. Other benefits provided by the e-book based on PBL are building the students' knowledge and stimulating them to think critically in solving real problems in the world so that the school graduates already have good competitiveness before going to the professional world.

\section{RESEARCH METHOD}

This a research aims to determine the effectiveness of accounting e-books that are problem-based learning oriented [13], [36], [37]. The research procedure used in the implementation of this research is adapted from the development research of Borg \& Gall [36], which consists of 10 stages, namely: Research and Information Gathering, Planning, Development of Initial Product Forms, Preliminary Field Testing, Main Product Revisions, Main Field Testing, Operational Product Revisions, Operational Field Testing, Final Product Revisions, and Dissemination, and Implementation.

This research was conducted at SMA Negeri 4 Surakarta. The population in this study were 120 students with a sample of 60 students divided into 30 control class students and 30 experimental class students. The sampling technique used was simple random sampling. Data collection was carried out by observation, interviews, questionnaires, document analysis, and tests. The data analysis 
technique used is descriptive statistics and inferential statistical analysis. Descriptive statistical analysis includes validation of expert data analysis and questionnaire data analysis. The data that has been scored is then converted into a percentage with the following formula:

$$
\mathrm{P}=\frac{\sum x i}{\sum x} x 100 \%
$$

Note:

$\mathrm{P} \quad$ : assessment percentage;

$\sum x i$ : number of answers from subjects;

$\sum x:$ number of most frequent answers

The obtained percentage is then transformed into a table for easy reading of the research results. The percentage range and qualitative criteria can be found based on the following table:

Table 1. Decision-Making Criteria

\begin{tabular}{ccc}
\hline $\begin{array}{c}\text { Achievement of learning } \\
\text { outcome }\end{array}$ & Qualification & Note \\
\hline $81-100 \%$ & Very good & No revision \\
$61-80 \%$ & Good & No revision \\
$41-60 \%$ & Fair & Revision needed \\
$21-40 \%$ & Less good & Revision needed \\
$0 \%-20 \%$ & Not very good & Revision needed \\
\hline
\end{tabular}

(Source: Riduwan, 2010).

Meanwhile, inferential statistical analysis is used to determine the effectiveness of accounting e-book oriented to problem-based learning. The effectiveness is viewed from inferential statistical analysis which is preceded by the prerequisite test, namely the normality and homogeneity test. The effectiveness is tested using the Two Independent Samples T-test.

\section{RESULTS AND DISCUSSIONS}

\subsection{Preliminary Research}

The preliminary study aims to explore preliminary data for developing an accounting ebook oriented to the problem-based learning method. Preliminary study analysis is carried out by literature review and field studies. The field studies analysis consists of curriculum analysis, the educator needs analysis, students' needs analysis, and infrastructure and facilities analysis.

The results of the analysis of the teachers' needs show that accounting teachers want to carry out learning activities using innovative media. The accounting teachers want to make accounting learning more active, interesting, enjoyable, and easier to understand. Besides, the teachers say that it is still difficult to develop appropriate instructional media so that the learning process is still teacher-centered, even though the learning activities desired by the 2013 curriculum must be student-centered. The results of the analysis of the students' needs show that they are less enthusiastic in following the learning process because the teachers only rely on the lecturing method. Also, the teachers do not yet apply innovative learning media for the delivery of the materials.

Based on the results of the needs analysis for media development planning, the researcher develops a learning medium called accounting ebook oriented to problem-based learning. The learning carried out using an accounting e-book can improve the students' learning outcomes by attracting their attention in the learning process and focusing on what is explained by the teachers. The students' motivation can be strongly enforced because the materials display is equipped with animation, music, text, and images.

The learning process supported with an accounting e-book can improve the learning outcomes by attracting the students' attention in the learning process and focusing on what is explained by the teachers to be motivated more in the learning. [35] stated that the students' ability improved well after using digital text (e-books) compared to textbooks, and the results of the ebook user satisfaction survey were very positive, meaning that they were satisfied with the learning using e-books. Furthermore, [38], [39] stated that the students' understanding increased significantly through learning using e-books. [40], [41] showed that e-books could improve quality, function, and 
help the students and educators in the learning process.

\section{2 Development Steps}

The product development steps include product planning, initial product draft, and validation. Product planning includes the preparation of KI, Basic Competencies KD, and learning objectives, making an outline for media planning (GBPM), making flow charts, collecting references, and programming. The initial product draft aims to create an e-book consisting of the Program Title, Instructions for Use, Learning Menu, Competency Standards, and Basic Competencies, Competency Achievement Indicators, Concept Maps, Learning Materials, Case Study Questions, Evaluation, and Developer Profiles. After the product is finished, it is necessary to test the product's feasibility before it is used in learning. The feasibility of the product is assessed from the results of the experts' validation, namely instructional media experts, subject matter experts, linguists, and practitioners.

Based on the description above, it shows that the feasibility of the product assessed by instructional media experts is $92.5 \%$, learning material is $83.3 \%$, by linguists is $100 \%$, and by practitioners is $91.7 \%$. The average product eligibility is $91.8 \%$, which means that it has a very good qualification. The average percentage of feasibility indicates that the product developed has conformed to specifications with the theory used to carry out product development. This percentage figure also shows that the product has the feasibility of being used as a learning medium. The feasibility value of a problem-based learningoriented accounting e-book needs to be supported by the value of the effectiveness of product use. Besides being suitable for use, it must also be proven to provide a good influence to improve learning outcomes.

\subsection{Testing Steps}

After carrying out limited, extensive, and field trials through the revision stage, the learning media becomes draft $\mathrm{V}$ which is then called the final product to be used in the implementation stage to assess its effectiveness. At this stage, the accounting e-book is applied to 30 students of XI
IPS 3 class as the experimental one, while class XI IPS 1 , totaling 30 , is the control one.

From the results of the pre-test between the control class and the experimental class, it can be seen that the mean pre-test score of the control group was 58.83 while the experimental class was 58.17. Furthermore, to prove that there was a significant difference in learning outcomes between the experimental class and the control class, the ttest was carried out and the significance value was obtained $0.795>0.05$, while the tcount was -0.261 $<1.693$ (t-table) so that H0 was accepted and H1 was rejected. It can be concluded that there is no significant difference between student learning outcomes in the experimental class and the control class during the pre-test.

From the posttest results, the average score of the experimental class was 83.33 while the control class was 77.17. Furthermore, the t-test obtained a significance value of $0.003<0.05$ while the $t$-count was 3.119> 1.693 (t-table), thus H0 is rejected and $\mathrm{H} 1$ is accepted and it can be concluded that there is significance. The difference between the experimental class and the control class based on the post-test scores.

Based on the pre-test and post-test scores between the experimental class and the control class there was an increase in the average value of learning outcomes in the experimental class by $25.17 \%$, while the increase in the control class was $18.33 \%$. Thus it can be stated that the increase in learning outcomes in the experimental class is higher than the control class.

The results of [39] stated that $90 \%$ of respondents agreed that using e-books was effective in improving their understanding. This finding also similar to [42] in their journal entitled, "Scholars in Malaysia use ebooks to help them in doing their college assignments anywhere and anytime". That e-books are easier to understand and especially needed to do assignments and projects. [43] showed that learning using e-books has considerable benefits for both students and educators. This proves that e-books are effectively used in the learning process.

\section{CONCLUSIONS}

Based on the results of the study, it can be concluded that accounting e-books oriented to problem-based learning models can effectively improve student learning outcomes. The pretest average value of the experimental class was 58.17, and after implementing the learning process using 
accounting e-books that were oriented towards problem-based learning there was an increase in learning outcomes by 83.33 , thus it can be seen that there was an increase in student learning outcomes by $25.17 \%$.

The increase in the average score of accounting learning before (pre-test) and after (post-test) using the accounting e-book oriented to problem-based learning model indicates that the accounting e-book is effective in improving the students' learning outcomes. The use of accounting e-book oriented to problem-based learning model has effectively and successfully improved the students' learning outcomes, and this is supported by statistical calculations and significance value (0.003) which is lower than 0.05 or $t_{-}$count 3.119 . Based on statistical calculations, there is a significant difference in the average score before (pre-test) and after treatment (post-test). Therefore, $\mathrm{H}_{1}$ is accepted and $\mathrm{H}_{0}$ is rejected, and it shows that the use of accounting ebook oriented to the problem-based learning model is effective to improve the students' learning outcomes.

\subsection{Implications and Suggestions}

Based on the discussions and conclusions, the research and development of the accounting e-book oriented to the problem-based learning model give the following implications:

1. The accounting e-book is one of the effective learning media to deeply understand the accounting materials

2. The accounting e-book has successfully improved the students' learning outcomes

3. The results of this research provide a framework for the educators and encourage them to use the learning media that are appropriate with the material characteristics in the achievement of learning outcomes.

4. The results can be used for the next accounting learning sessions to help and assist the students to deeply understand the learning materials

5. The accounting e-book is practical and easy to use so that it allows students to learn independently. Besides using a laptop and computer, the e-book can also be operated through smartphones so that the students can access it anywhere and anytime.

The next researchers or educators may add some modifications for the sustainability of the accounting e-book oriented to the problem-based learning model by giving additional materials or applying the same method on other subjects but using the different models and applying other supporting instruments like videos or images.

\section{REFERENCES}

[1] Kemendikbud, Renstra Kemendiknas. Jakarta: Kemendikbud, 2014.

[2] Mulyasa, Pengembangan dan Implementasi Kurikulum 2013. Bandung: Bandung: PT Remaja Rosdakarya, 2013.

[3] J. V. Andrea Menin, Jenny Perham and A. Wachtel, "Using e-books to create shared learning experiences between students of differing abilities," vol. 1243, no. June, 2016, doi: 10.1080/19411243.2016.1153375.

[4] M. Letchumanan and R. Ahmad, "Utilization of e-book among University Mathematics Students," vol. 8, no. 5, pp. 580-587, 2010, doi: 10.1016/j.sbspro.2010.12.080.

[5] N. Nguyen, "Designing and using interactive e-books in," vol. 11, no. 1, pp. 75-98, 2015.

[6] M. Mohammed and A. Ebied, "The effect of interactive e-book on students, achievement at Najran University in computer in education course," vol. 6, no. 19, pp. 71-83, 2015.

[7] S. Beadenkopf, "e-Books: Wave of the future or just a passing shower? In I. Gibson et al. (Eds.)," Proc. Soc. Inf. Technol. Teach. Educ. Int. Conf., pp. 2429-2434, 2009.

[8] I. Rowlands, D. Nicholas, W. Farm, and H. R. Jamali, “e-books ?," no. May 2014, 2007, doi: 10.1108/00012530710839588.

[9] Husamah, Desain Pembelajaran. Jakarta: Prestasi Pustaka., 2013.

[10] Sugiyanto, Model-Model Pembelajaran Inovatif. Surakarta: Yuma Pustaka, 2009.

[11] J. Hou, "Project and Module Based Teaching and Learning," Int. J. Soc. Behav. Educ. Econ. Bus. Ind. Eng., vol. 8, no. 3, pp. 791-796, 2014.

[12] I. W. Martanti and D. Priantinah, "Penerapan Model Pembelajaran Problem-Based Learning Untuk Meningkatkan Pemahaman Konsep 
Dan Motivasi Belajar," J. Pendidik. Akunt. Indones., vol. 12, no. 1, 2014, doi: 10.21831/jpai.v12i1.5167.

[13] Nusa Putra, Reseacrh \& Development, Penelitian dan Pengembangan Suatu Pengantar. Jakarta: PT. Raja Grafindo Persada, 2012.

[14] F. Almadani, Buku Digital Interaktif. Accessed

http://firmanalmadani.wordpress.com on 28 January 2020., 2014.

[15] J. O. Borchers, "Electronic books: Definition, genres, interaction design patterns," Conf. Hum. Factors Comput. Syst. CHI99 Work. Des. Electron. Books, p. 8, 1999.

[16] B. J. Onggo, Success With E-book. Bandung: Syaamil Cipta Media, 2007

[17] G. Sadlo, "Using problem-based learning during student placements to embed theory in practice," Int. J. Pract. Learn. Heal. Soc. Care, vol. 2, no. 1, pp. 6-19, 2014, doi: 10.11120/pblh.2014.00029.

[18] V. Parson and S. Bignell, "Using problembased learning within 3D virtual worlds," Cutting-Edge Technol. High. Educ., vol. 4, no. September, pp. 241-261, 2011, doi: 10.1108/S2044-9968(2011)0000004014.

[19] K. B. Carbonell, A. Dailey-Hebert, M. Gerken, and T. Grohnert, Problem-based learning in hybrid, blended, or online courses: Instructional and change management implications for supporting learner engagement, vol. 6, no. PARTG. Emerald Group Publishing Limited, 2013.

[20] C. Schechter, "Switching cognitive gears: Problem-based learning and success-based learning as instructional frameworks in leadership education," J. Educ. Adm., vol. 49, no. 2, pp. 143-165, 2011, doi: 10.1108/09578231111116707.

[21] Y. Chomsatun, A. Wijayanti, and K. Titisari, "Model Pembelajaran Akuntansi untuk Meningkatkan Kompetensi Mahasiswa," Bul. Stud. Ekon., vol. 18, no. 2, pp. 126-135, 2013.

[22] M. Asyari, M. H. I. Al Muhdhar, H. Susilo, and I. Ibrohim, "Improving critical thinking skills through the integration of problem based learning and group investigation," Int. J. Lesson Learn. Stud., vol. 5, no. 1, pp. 3644, 2016, doi: 10.1108/IJLLS-10-2014-0042.
[23] K. Sejpal, "Models of Teaching: The Way of Learning," Int. J. Res. Educ., vol. 2, no. 3, pp. 18-24, 2013.

[24] J. Kettunen, L. Kairisto-Mertanen, and T. Penttilä, "Innovation pedagogy and desired learning outcomes in higher education," Horiz., vol. 21, no. 4, pp. 333-342, 2013, doi: 10.1108/OTH-08-2011-0024.

[25] R. Lile and C. Bran, "The Assessment of Learning Outcomes," Procedia - Soc. Behav. Sci., vol. 163, pp. 125-131, 2014, doi: 10.1016/j.sbspro.2014.12.297.

[26] Sudjana, Penilaian Hasil Proses Belajar Mengajar. Bandung: Bandung: PT Remaja Rosdakarya, 2011.

[27] Kunandar, Penilaian Auntentik (Penilaian Hasil Belajar Peserta Didik Berdasarkan Kurikulum 2013). Jakarta: PT. Raja Grafindo Persada, 2013.

[28] Rusman, Belajar dan Pembelajaran Berbasis Komputer Mengembangkan Profesionalisme Guru Abad 21. Bandung: Alfabeta, 2013.

[29] A. Susanto, Teori Belajar dan Pembelajaran di Sekolah Dasar. Jakarta: Kencana Prenada Media Group, 2013.

[30] D. J. P. Euis Karwati, Manajemen Kelas (Classroom Management) Guru Profesional yang Inspiratif, Kreatif, Menyenangkan, dan Berprestasi. Bandung: Alfabeta, 2014.

[31] G. Cumaoglu, E. Sacici, and K. Torun, "EBook versus Printed Materials: Preferences of University Students," Contemp. Educ. Technol., vol. 4, no. 2, 2020, doi: 10.30935/cedtech/6096.

[32] N. Zahara, D. Djufri, and M. A. Sarong, "Optimalisasi Pembelajaran Dengan E-Book Dan Media pembelajaran Berbasis Multimedia Untuk Meningkatkan Hasil belajar Siswa Kelas X SMA Pada Materi Dunia Tumbuhan," Biot. J. Ilm. Biol. Teknol. dan Kependidikan, vol. 2, no. 2, p. 105, 2017, doi: 10.22373/biotik.v2i2.243.

[33] F. Putrawansyah, Zulkardi, and S. Ms, "Pengembangan Digital Book Berbasis Android Materi Perpindahan Kalor Di Sekolah Menegah Atas," Indones. J. Netw. Secur., vol. 5, no. 4, pp. 39-48, 2016.

[34] G. Johnson and G. Buck, "Electronic books versus paper books: Pre-service teacher preference for University study and 
recreational reading," Int. J. Humanit. Soc. Sci. Educ., vol. 1, no. 8, pp. 13-22, 2014, [Online].

Available:

https://espace.curtin.edu.au/handle/20.500.119 $37 / 5525$.

[35] K.-H. Y. C.-S. Park, M. Kim, "Design and implementation of a problem-based digital textbook," Int. J. Softw. Eng. Its Appl., vol. 6, no. 4, pp. 213-222, 2012.

[36] Sugiyono, Metode Penelitian Pendidikan (Pendekatan Kauntitatif, Kualitatif, dan $R \& D)$. Bandung: Alfabeta, 2015.

[37] N. S. Sukmadinata, Metode Penelitian Pendidikan. Bandung: PT. Remaja Rosdakarya, 2007.

[38] H. Y. Chen and S. J. Jang, "Exploring the reasons for using electric books and technologic pedagogical and content knowledge of Taiwanese elementary mathematics and science teachers," Turkish Online J. Educ. Technol., vol. 12, no. 2, pp. 131-141, 2013.

[39] T. Yoon, "Beyond the traditional reading class: The application of an e-Book in EFL English classroom," Int. J. Res. Stud. Lang. Learn., vol. 2, no. 1, pp. 17-26, 2012, doi: 10.5861/ijrsll.2012.93.

[40] C. Lai, "Integrating E-books into Science Teaching by Preservice Elementary School Teachers," J. Educ. Sci. Environ. Heal., vol. 2, no. 1, p. 57, 2015, doi: 10.21891/jeseh.43277.

[41] C. N. Chen, S. C. Chen, S. H. E. Chen, and S. C. Wey, "The effects of extensive reading via e-books on tertiary level EFL students' reading attitude, reading comprehension and vocabulary," Turkish Online J. Educ. Technol., vol. 12, no. 2, pp. 303-312, 2013.

[42] R. Ismail and A. N. Zainab, "The pattern of e-book use amongst undergraduates in Malaysia: A case of to know is to use," Malaysian J. Libr. Inf. Sci., vol. 10, no. 2, pp. 1-23, 2005.

[43] J. O. Donoghue and H. Worton, "A Study Into The Effects Of eLearning On Higher Education Gurmak Singh," J. Univ. Teach. Learn. Pract., vol. 133, no. 3, pp. 547-553, 2005, [Online]. Available: http://www.ncbi.nlm.nih.gov/entrez/query.f cgi? $\mathrm{cmd}=$ Retrieve $\& \mathrm{db}=$ PubMed $\&$ dopt $=$ Cit ation\&list_uids=12443913. 